\title{
THE PROBLEMS OF THAI STUDENTS IN MASTERING ENGLISH SPEAKING SKILLS IN THE ISLAMIC UNIVERSITY OF LAMONGAN
}

\author{
Aleeya Tahe \\ aliyatotoyong2529@gmail.com \\ English Language Education Department, Faculty of Teacher Training and Education, Universitas Islam \\ Lamongan
}

\begin{abstract}
English speaking skills are very important to communicate in the world. Most of the people communicate with other people by using speaking skills. The difficult skill to master in learning English for Thai students is speaking skills, especially those who are learning English in Indonesia speaking skill seems to be the most difficult one to learn. Whereas, it is the most important skill that leads to effective communication between people. Speaking skill is considered as the most important means of communication. Although students still have problems with their English speaking skills. Thai students who study at the English department academic still get problems in speaking skills and it needs overcoming with their English problems. The main objective of this study is to know the problems of Thai students in mastering English speaking skills in the Islamic university of Lamongan (Indonesia).
\end{abstract}

Keywords: Thai Student, English speaking skill

\section{INTRODUCTION}

In globalization, English is very important for international communication. English is the dominant language used by many people around the world in both oral and written. It is the lingua franca used for international communication in all aspects of human life such as education, culture, business, politics, economics, administration, science, and academia. Learning speaking skill is, then, the most important aspect of learning a foreign language or second language and will measure success based on the ability to speak in a language (Nunan, 1995:39). So, learning to speak is not an easy thing. English is also important for Thai students because Thailand is a popular tourist country. English is also important for Thai students because Thailand is a popular tourist country. According to Dr.Teerakiat Jareonsettasin, Minister of Education, Thailand (in Dailynews, 2019). English is a foreign 
language to learn in Thailand because it is needed to communicate, work, and transfer knowledge. He also wants to increase English language education standards at all levels. The program to increase the standards is reasonable because Thai students want to learn English based on their needs and some students lack the opportunities to learn and practice English speaking. The difficult skill to master in learning English for Thai students is speaking skill. Every language is difficult, but for Thai students especially who are learning English in Indonesia speaking skill seems to be the most difficult one to learn. Whereas, it is the most important skill that leads to effective communication between people. Speaking skills is considered the most important means of communication. Thai students in the English Department of FKIP have been learning English language since elementary school until now. They have spent about 12-16 years studying English. In one day, they study English about 1 or 2 hours. But, they still cannot speak English well. A why-question then appears. Now, there are 22 Thai students who learn In Indonesia, particularly in Lamongan. 8 students are studying at Islamic University of Lamongan and 14 students are studying at Darul Ulum Islamic University Lamongan.They mainly uses Melayu and Thai language in daily communication. When they talk to friends or other people, they will use Melayu language for easy communication. But if talking to an adult or communicating with government officials, they must use Thai language to communicate politely because Thai language is the official language. However, even though they are studying in Indonesia, they always speak Melayu or Indo language to communicate with friends, teachers and others, except students who study English major will speak English in the classroom. But most of them speak Melayu and Thai language. Based on preliminary observation, Thai students, especially those who are learning 
at the English Department, seem to get difficulties in oral or spoken communication. It is possible because their mother tongue is Melayu language and their second language is Thai. They frequently cannot speak or communicate well in English in daily life. What makes it worse is that, in some occasions Thai students are, then, becoming speechless. They are reluctant to speak. They tend to be silent because they seem to be afraid of making mistakes. They are seen to be shy and not confident to speak English. If that continues, their English speaking skill will remain relatively low. The problem of Thai students in English speaking skills into the linguistic factor and non-linguistic factor analysis. According to Sabtono in Luluk (2012), the problems in language learning are divided into two factors of the problem; they are linguistic factors and non-linguistic factors. Linguistic problems are problems about languages itself and Non-linguistic problems are the problems that affect language learning. This theory is appropriate for Thai students who face the problem in learning English speaking skills.

\section{The Problems in Learning Speaking}

Language learning has two types of problems; they are linguistic factors and non-linguistic factors (Sadtono, 1995 in Luluk 2012).

1. The Linguistic factors, there are vocabulary, grammar, pronunciation.

2. Non-linguistic factors that may influence language learners include teachers, methods, material, motivations, facilities, students, and etc.

\section{Linguistic Problem}

Linguistics is the study of languages. Linguistic problems are the factors which come from the language itself and cause difficulties in language. In general, the linguistics of learners consists of vocabulary, grammar and 
pronunciation that are language problems.

\section{a. Vocabulary}

Vocabulary is a group of words, a sound group that have meaning in speaking and writing. Vocabulary is an important part of every language to communicate the meaning, needs or knowledge in using language in communication.

\section{b. Grammar}

Grammar is the learning of correct sentences and structures to increase skills and ability to use language in speaking and writing. Grammar is an important role in creating words and sentences (oxford, 2008).

\section{c. Pronunciation}

Pronunciation in English is one of the hardest skills to learn speaking skills. And is the most important thing in speaking. Learners must be proficient in communication and fluency in pronunciation. Correct pronunciation is very essential to develop speaking skill.

\section{Non-Linguistic Problem}

\section{a. The Student}

In the teaching and learning process students play an important part. They have different talents, styles, attitudes and others. The best time to learn English speaking skills is the language needs of the students and has free time, motivation and opportunity at that time.

\section{b. The Teacher}

A teacher is someone who helps students and gives educational advice and helps students to learn and understand. The most influential factor in student learning is the teacher, knowledge, expertise, quality of the teacher. And teachers have many methods in teaching to enable students to learn and be effective and successful. 


\section{c. Method}

Method is the way of teaching used in the classroom or outside the room. Teachers teaching methods based on a set of specific theories. The method can be determined from the activities types, the roles of teachers and learners.

\section{d. Material}

Teachers and learners are able to create activities through the teaching and learning process to develop media in the classroom to inspire, practice various language skills. Material developers may write textbooks, tell stories in the class, read the poem, express an idea or make media interesting teaching and learning materials for effectively learned (Tomlinson 2011).

\section{e. Facility}

Facilities are something designed, built, or is a workplace, facility, or piece of equipment that is created for a particular purpose and something that makes an action, operation, or activity easier (oxford,2008). Facilities of study are able to improve teaching and learning process there are the textbooks, the laboratories teaching media, classroom, and also the libraries.

\section{f. Motivation}

Motivation is important for students and is the power to stimulate desire, love, need, pressure, or psychological mechanisms that motivate a person or group to achieve their desired results.

Different from Sadtono, Muhammad in the international journal “challenges of learning English as a foreign language (EFL) by non-native learners", classifies the Non-Linguistic problems into Environment, Attitude, and Accent. More elaboration of the classification is explained below. 


\section{a. Environment}

The environment has

influenced humans for a long time because every environment has an influence on the mind and behavior of the learners. The learning environment means the things that surround the learner, such as the condition of the classroom in which the design and placement of learning materials and tools are used. And the atmosphere of the classroom is formed by the coexistence of members consisting of students and teachers, claimed by (Areeya Starut, 2013). The environment in the school is another factor that helps to encourage students to learn and develop faster.

\section{b. Attitude}

Attitude is another emotional factor in learning and it is the way that you think and feel with someone or something and to do something shows how you think and feel. Some English learners have negative thinking about language, which may lead to lack of motivation, lack of self-confidence, anxiety, stress, and fear of making mistakes.

\section{c. Accent}

Another problem that Thai students may face in learning English is accent because they do not know the perfect accent and good Accents. Accent is the way of pronouncing words. English language has different accents such as American and British. If the learner has an accent like a native speaker, it will be very good for communication and make it easier to understand.

\section{English as a Foreign Language in Thailand}

English is one of the common languages in the world today. In Thailand, English is a foreign language (EFL) and English became the most prestigious foreign language during the reign of King Rama (1868-1910). Nowadays, English is the important language to be learned especially for 
Thai people in developing education, business, and personal development as well. English is the language that people use in international communication. Speaking skills are therefore important for Thai people to develop themselves. In Thailand, English is a foreign language (EFL), not a second language (L2). However, English is an important language to learn because it is needed for education and communication.

\section{RESEARCH METHOD}

The research is descriptive qualitative with a case study as design of the research. The instruments for collecting data were interview and observation. The data collected were about the problems of Thai students in mastering English speaking skills. The subject of the research is four Thai students of the English Department at Islamic university of Lamongan (UNISLA).

\section{FINDINGS AND DISCUSSION}

The subjects were interviewed on February 4, 6, 14 and March 2, 2020. -The interviews were done to four Thai students who study at the English Department of Islamic University of Lamongan. To make it easier to understand, the researcher displays the data findings in the following ways. First, the data of problems faced by Thai students are called Data of Problems and coded as Data P. Then, when it deals with the kinds of problems, it is followed by the first letter of the kinds of problems. For instance, when the problems deal with Grammar, they are, then, written as Data P-G. When they are associated with Vocabulary, they are named as Data P-V. It goes so for other kinds of problems. After finishing the interview with the four Thai students, the researcher can find the data and identify the problems. Some of the data findings related to problems faced 
by Thai students can be seen in Data (1),

(2), (3) and (4) below.

(1) "I confused when I communicated with friends, some words is difficult to understand because their pronunciation and some words my friend not understand with my pronunciation because the pronunciation of each person is different", --- Data P-P. 1, subject1, February 4, 2020.

(2) "When I talk to my friends, I get confused about grammar and I don't know how to use past or present sentence", ---Data P-G. 2, subject3, February 14, 2020.

(3) "The vocabulary is one of my problems to speak English. When I want to speak English I always think about vocabulary and worry about that because I lack in vocabulary. That makes me unconfident to communicate with English language", ---Data P-V. 2, subject1, February 4, 2020.

(4) "The accent is one of my problem in speaking skill, in here some teacher's accent is wrong that makes me not improve to speak English", --Data P-A. 1, subject1, February 4, 2020.

(5) "For environment is very important but environment in campus is full of friends who speak Indonesia and Java language to communicate", -

-- Data P-E. 2, subject2, February 6, 2020.

The four data above are only examples of the data findings presented.

The other findings in line with the kinds of problems, they are problems of Pronunciation (P-P), Problems of Method
(P-Me), Problems of Materials (P-Ma), Problems of Facilities (P-F), Problems of Accent (P-A), Problems of Motivation (P$\mathrm{M})$, Problems of Environment (P-E), and the rests, can be completely seen in Appendices 1.

As being discussed previously, the researcher also tries to find the answers about the efforts done by Thai students to solve the problems in mastering speaking skills. To get the answers, the interviews are also containing questions about the efforts done by the four Thai students. The students' answers are then identified and coded almost the same way as those of Problems faced above. Data of Solutions done is named as Data $\mathbf{S}$. Then, when it deals with the kinds of solutions, it is followed by the first letter of the kinds of solutions. For instance, when the solution deals with the problems of Grammar it is, then, written as Data S-G. When it is associated with Vocabulary, it is named as Data S-V. It goes so for other kinds of problems. 
From the interviews asking about the efforts done, the researcher can find the data and identify efforts done by the Thai students. Some of the data findings related to the efforts done by Thai students can be seen in Data Presentation (5), (6), and (7) as the following.

(6) "I always listen English songs, watch movies by English (sub-title), and learn English on Facebook, Instagram and YouTube", ---Data SV. 1, subject1, February 4, 2020.

(7) "I always write new vocabulary when I read a book or newspaper", --Data S-V. 2, subject3, February 14, 2020.

(8) "I write new vocabulary and new sentences on YouTube, Facebook and memorize vocabulary", ---Data S-G. 1, subject4, March 2, 2020.

This section presents the discussion based on the above research results. From the data collection, it is found that Thai students face some problems in English speaking skill. This discussion relates to the problems of Thai students in mastering English speaking skills. The problems in learning English consist of linguistic factors and nonlinguistic factors, based on (Sadtono, 1995 in Luluk 2012). The results of the interview showing that four Thai students in the English Department face problems in mastering English speaking skill due to linguistic and non-linguistic problems can be seen in the table of the interview above. In terms of Linguistic factors, there are grammar, vocabulary, and pronunciation. The Non-Linguistic ones are divided into two parts based on Sadtono and Mohammed's statement. Sadtono states that Non-Linguistic problems include the teacher, student, method, facility, material and motivation. Meanwhile, Muhammed says that it covers environment, altitude and accent.

\section{Linguistic Problems}

Based on the interview with the Thai students in the English Department of Islamic University of Lamongan, it is found that they have linguistic problems in mastering English speaking skill. The linguistic problems are the difficulties 
faced by the students which come from the linguistic factor itself. The problems are in their vocabulary, grammar, and pronunciation. Non-linguistic problems, In addition to Linguistic problems, Thai students at the English Department of FKIP Unisla also seem to face NonLinguistic problems. In this research, the discussion of non-linguistic problems is based on Sadtono's statement and Mohammed's as explained in the introduction. Sadtono states that NonLinguistic problems include the teacher, student, method, facility, material and motivation. Meanwhile, Muhammed says that it covers environment, altitude and accent. The Thai Students' Efforts to Solve Their Problems to Improve Their English Speaking Skill, it is found that the Thai students have done their efforts or found their ways to solve the problems in improving English speaking skill. They are: finding the ways to learn English better and taking a good note in learning English. All Thai students try to find ways to improve their English speaking skill well. In addition to teachers' help, they also make their own efforts to overcome their problems.

The research findings from the interview must be explained and analyzed. The researcher used descriptive qualitative analysis because this research wants to describe and to understand the problems of English speaking skill and the efforts done to overcome in the research with the title "The Problem of Thai Students in Mastering English Speaking Skill in The Islamic University of Lamongan". The pronunciation still becomes a problem for the four Thai students in learning English speaking skills. The problems of pronunciation influence their fluency and confidence in speaking English fluently. For the grammar Thai students still had problems. They were all worried about grammar in learning English. And it was found that two Thai students had problems with vocabulary in speaking English. It was a problem in learning English 
speaking skills and it made them unable to speak English faster. After interviewing all Thai students in the English department of FKIP (Unisla) and having done the analysis, the researcher concluded that the main problems are pronunciation, grammar and vocabulary. Those are some causes of Thai student's problems. The problems that Thai students' faces are most concerned about are pronunciation followed by grammar and the last is vocabulary.

The results show that teaching methods are an important part in learning English speaking skills and most teachers use Indonesia language to teach in the class. It causes Thai students to understand but cannot speak English fluently and method is a problem for them. Teachers should have interesting teaching methods and should use full English in teaching or explaining to make students familiar with the English language. Three of four Thai students still encounter problems with the facilities to learn English speaking skills because the facilities in the university are not enough to learn English speaking skills and make students not interested in speaking English. Thus, facility is one of the factors in supporting the learning of English speaking skills. That means, the faculty of English or in university should have English area or English laboratories for the students to practice English and. It helps them feel to enjoy and interested when learning English and can help students speak English more fluently. And three of four Thai students had motivational problems to practice English speaking skills. Sometimes they lack motivation to study English because they are worried about English speaking skills. However, if the students lack motivation in themselves to study English language they cannot speak English. So, motivation is one part that encourages self-development and it is an important ingredient in one's success. For environment, Three of Thai 
students in the English department of FKIP have problems in learning English speaking skills in terms of environment because environment is a factor that supports and makes learning English speaking skill easier. Environment is one factor which enables the learning of English speaking skills and the other skills faster. If the environment around them is full of people speaking English, it will make them speak English easier, better and speak English quickly. The researchers reveal three of four students still have problems with accent. Thai students have accents like Thai people more than English. Sometimes they are shy with the accent because the accent is not clear. It caused them not to speak English. For Thai students, the accent is an important part of speaking English. They need an accent like a native speaker. It will make it easier to communicate. Such as, if they speak English with an unclear accent and not good accent it makes the listener not understand what they want to communicate. If the accent is good, English is also good. So, according to the interview with four Thai students in the English department of FKIP (Unisla) about Non-linguistic problems mentioned above, some students have the same problems and some others students have different problems due to many factors as stated in data above. Non-language problems are also problems that influence the learning of English speaking skills. The problems faced by Thai students who learn English speaking at English Department of FKIP UNISLA can be resumed as problems of linguistic and Non-Linguistics.

\section{Linguistic Problems cover}

Problems of Grammar, Vocabulary and Pronunciation. In this case, Vocabulary Problems are experienced by 2 students or interviewees, Grammar problems by 3 interviewees and Pronunciation problems by all interviewees. Next, in this research, Non-Linguistic Problems as stated by Sadtono consists of Problems of Student, Teacher, Method, Facility and Motivation. 
The results show that all Thai students (interviewees) experience the problems of Method. Then, 3 three students get problems both in Facility and Motivation. Based on Mohammad's classification, the Problems are categorized as Problems of Environment, Altitude and Accent. The interview results reveal that three students have problems in terms of Environment and Accent. From students' point of view, it can be explained that Student 1 (interviewee 1) experiences both Linguistic and Non-Linguistic Problems. In Linguistic Problems, she gets difficulties or problems in Vocabulary, Grammar and Pronunciation. In NonLinguistic ones, she experiences the problems in method, facility, motivation, environment and accent.

\section{Then, Student 2 (interviewee 2)} also undergo both Linguistic and NonLinguistic Problems. She has problems of Grammar and Pronunciation in the Linguistic Problem category. In Non-
Linguistic ones, she undergoes the problems of Method, Facility, Motivation and Environment.

Next, Students 3 (interviewee 3) suffers both Linguistic and Non-Linguistic Problems as well. In Linguistic Problems, he gets difficulties in grammar, pronunciation and vocabulary. In NonLinguistic ones, he suffers the problem in Method, Motivation, Environment and Accent.

Last, Student 4 (interviewee 4) faces both Linguistic and Non-Linguistic Problems. In Linguistic Problems, she gets the problem of pronunciation. In NonLinguistic ones, she feces the problem in Method, Facility and Accent.

As stated previously that there is a relation between or among linguistic and non-linguistic problems. They are interrelated and the direction of the interaction can go both from linguistic to non-linguistic pattern, or vice versa. Firstly, motivation is related to the 
problem of pronunciation, grammar and vocabulary. If the students do not have motivation to learn English, it will make them unable to speak English well and it will affect them. Secondly, the environment has a relation with pronunciation and vocabulary because most students are talking in their own language (Javanese). It makes the Thai students unable to improve their ability to speak English fluently. Thirdly, facilities and methods are interrelated because the facilities and methods of teaching are the factors that make the students feel not bored when learning English and make English more interesting. Lastly, accent is associated with pronunciation. Accent is very often different from one another, either among persons, places or nations. The accent may be related to the speakers' residence as occurring in the university. The students and the lecturers have their local accent and they frequently mispronounce English words. Yet, even though the accent is different, it will be acceptable if they have right and acceptable pronunciation. In terms of the Non-Linguistic factors of Sadtono, (1995) and Mohammed (2018), it shows that the non-language influence the learning of English speaking skills of Thai students in English department. Based on Sadtono (1995), the problems are facility, method, and motivation. Based on Mohammed's (2018), they are environment and accent. Based on the interviews with all Thai students in English department, it is revealed that learning problems are caused by non-language factors. The results of the study of Thai students showed that there were five non-linguistic problems faced by students in speaking, namely, method, facility, motivation, environment and accent. These are the problems of Thai students in learning English speaking skills faced by Thai students in the English Department of FKIP, and they influence the Thai students' speaking skill development. In this study, it is also found 
that all Thai students have made efforts to overcome the problems. First, they try to find their own ways to learn English better using some methods or strategies for learning. They listen to English songs, watch movies by English (sub-title), and read English books. Second, they do notetaking methods.

\section{CONCLUSION}

\section{CONCLUSION}

From this research study, the researcher can conclude that the problems faced by Thai students in learning English speaking skills was because they did not master the three main components of vocabulary, grammar, and pronunciation. Besides those problems, they also had problems with their mother tongue (Thai language). The mother tongue still affected their communication because they did not use English in daily life to communicate. Consequently it made them feel worried, shy and not confident in speaking English when they wanted to speak.

As a result, many Thai students were not really good at speaking English. So, English language for Thai students is very important in learning communication and expression, especially English speaking skills. Although these problems will be obstacles in learning speaking skills, they try to speak and practice all the time to improve their skills. Thai students have a way of solving their problems to improve in mastering speaking English skill, and have appropriate solutions in learning English.

After the analysis, the researcher finds the problem and the efforts done by Thai students as their solution to improve English speaking skills of Thai students in the English department. The researcher concludes that from the result of the analysis. It is proven that Thai students still have a problem in learning 
English speaking skills, namely, linguistic factors and non-linguistic factors. Even though they have problems or difficulties, they have made efforts to overcome their problems and to improve their English speaking skills in order to be successful.

\section{REFERENCES}

Areeya Starut. (2013). The Environment at Management in the Schools Ratchathewid Disrictrict, Abministation: Srinakharunwirot University. Bangkok, Thailand.

Darasawang, Pornapit. (2007). English Language Teaching and Education in Thailand: A Decade of Change English in Southeast Asia: Varieties, Literacies and Literatures. Newcastle D. Prescott (Ed.) book (pp. 187-204). UK: Cambridge Scholars Publishing.

Nunan, David. (1995). Language Teaching Methodology: A Textbook for Teachers. New York:Prentice Hall.

Mohammed H. Mohammed. (2018). International Journal of Social
Science and Economic Research (Challenges of Learning English As A Foreign Language (EFL) By Non-Native Learners. International Journal of Science and Economic Research, (Online), 3 (4): 13811400, (www.Ijsser.Org), 21 May 2019.

Oxford University Press. (2008). Learner's Pocket Dictionary. Fourth Edition: Oxford University Press.

Prijambodo V. Luluk. (2012). Motivation: A Supporting Factor of the Success in Second Language Acquisition. Universitas Katolik Widya Mandala Surabaya, Magister Scientiae, $\quad 31(1)$ : $\quad$ Pp47-58, (Online), (http://journal.wima.ac.id/index.ph p/Magister_Scientiae/issue/view/8), Maret 2012.

Tomlinson, Brian. (2011). Materials Development in Language Teaching, Second Edition. Combridge University Press.

Teerakiat Jareonsettasin. Thailand. (2019). The Prime Minster Suggested the Ministry of Education To Train Thai Children To Absorb In Learning English (Online), https://www.dailynews.co.th/educa tion/698260, 13 March 2019. 